\title{
Analisis Pengaruh Jumlah Penduduk dan Akseptor KB Aktif Terhadap Angka Pra Sejahtera di Desa Borong Pa'la'la
}

\author{
Nur Ismi Tahir \\ Mahasiswa Prodi Matematika-FST, UINAM, Nismi2222@gmail.com \\ Ilham Syata \\ Prodi Matematika-FST, UINAM, Ilham.syata@uin-alauddin.ac.id
}

\begin{abstract}
ABSTRAK, Tujuan penelitian ini adalah untuk mengetahui pengaruh Jumlah Penduduk $\left(X_{1}\right)$ dan Akseptor KB Aktif $\left(X_{2}\right)$ terhadap Pra Sejahtera $(Y)$ di Desa Borong Pa'la'la tahun 2010-2018. Penelitian ini menggunakan metode analisis regresi linear berganda dengan melakukan pendugaan model, uji kelayakan model, menentukan model terbaik, uji asumsi dan menghitung koefisien determinasi. Hasil penelitian menunjukkan bahwa variabel jumlah penduduk dan akseptor KB aktif berpengaruh negatif dan signifikan terhadap variabel pra sejahtera di Desa Borong Pa'la'la.
\end{abstract}

Kata Kunci : Pra Sejahtera, Regresi Linear Berganda.

\section{PENDAHULUAN}

Sebagai negara berkembang, Indonesia dihadapkan pada masalah kemiskinan atau pra sejahtera yang tidak bisa diabaikan begitu saja. Padahal, kemiskinan merupakan salah satu masalah sosial bangsa Indonesia. Kemiskinan merujuk pada keadaan dimana seseorang tidak dapat memenuhi kebutuhannya sesuai dengan standar kehidupan di lingkungannya. Sulawesi Selatan merupakan salah satu provinsi di Indonesia yang juga tidak terlepas dari masalah kemiskinan. Ini telah menjadi masalah kompleks dari kualitas hidup yang buruk, pendidikan dan kesehatan masyarakat. Selain itu, kemiskinan merupakan salah satu kendala terbesar seseorang untuk mendapatkan kehidupan yang sejahtera. Pada dasarnya kesejahteraan adalah hak setiap warga negara Indonesia. Setiap warga negara berhak menikmati kehidupan yang layak, terbebas dari kemiskinan, dan berhak mencari kehidupan yang layak bagi umat manusia.

Berdasarkan hasil SUSENAS Maret 2019, jumlah penduduk miskin di Provinsi Sulawesi Selatan pada bulan Maret tahun 2019 sebanyak 767.800 jiwa atau mencapai $8,69 \%$ dari total penduduk. Jumlah penduduk miskin di Provinsi Sulawesi Selatan berfluktuasi setiap tahunnya. Jika dibandingkan dengan kondisi pada bulan
Maret 2018, penduduk miskin telah mencapai 9,06\% (792.640 jiwa) kemudian turun menjadi $0,37 \%$. Nilai absolutnya pun mengalami penurunan sebesar 24.840[1].

Banyak penelitian yang berkaitan dengan kemiskinan. Seperti yang dilakukan oleh Afifatuz Zahra, dkk., yang menjelaskan bahwa untuk meningkatkan kesejahteraan rakyat Indonesia atau mengentaskan kemiskinan hendaknya fokus pada peningkatan sumber daya manusia melalui pendidikan yang adil dan berkualitas. Kedua, asuransi kesehatan akan menjaga produktivitas kesehatan yang baik dan tentunya menyediakan perumahan yang layak[2].

Beberapa penelitian sebelumnya rata-rata menggunakan data satu periode waktu. Berbeda dengan penelitian ini yang menggunakan data time series, karena nantinya dapat melihat pengaruh suatu variabel yang signifikan selama periode waktu yang dijadikan penelitian. Kemudian, penelitian ini menggunakan metode analisis regresi linear berganda. Alasan penggunaan metode ini adalah karena dapat secara akurat menampilkan pengaruh variabel independen dengan variabel dependen. Dikatakan akurat, karena berbagai pengujian terhadap variabel hingga diperoleh variabel dengan model terbaik.

Oleh karena studi kasus tersebut berkaitan dengan penggunaan metode yang akan menjadi penelitian, sehingga peneliti tertarik untuk membahas "Implementasi Regresi Linear Berganda dalam Meninjau Pengaruh dari Jumlah Penduduk dan Akseptor KB Aktif Terhadap Angka Pra Sejahtera di Desa Borong Pa'la'la". 


\section{TINJAUAN PUSTAKA}

\section{Konsep Uji Regresi Ganda}

Uji regresi ganda pengembangan dari uji regresi sederhana. Jika variabel independen paling sedikit dua atau lebih, tujuannya adalah untuk memprediksi nilai variabel dependen (Y). Uji regresi berganda adalah alat yang digunakan untuk memprediksi pengaruh dua atau lebih variabel independen terhadap satu variabel dependen (untuk membuktikan ada tidaknya hubungan fungsional atau hubungan kausal antara dua atau lebih variabel independen $\left(X_{1}\right)$, $\left(X_{2}\right), \quad\left(X_{3}\right), \ldots,\left(X_{n}\right)$ dengan satu variabel dependen[3]. Bentuk umum persamaan regresi untuk $\mathrm{k}$ variabel independen dapat dirumuskan sebagai berikut.

$\hat{Y}=a+b_{1} X_{1}+b_{2} X_{2}+\cdots+b_{k} X_{k}+\varepsilon_{i}$ (2.1)

\section{Uji Asumsi Klasik}

a. Uji Normalitas

Data tersebut harus memiliki asumsi bahwa data tersebut berdistribusi normal [4].

b. Uji Multikolinearitas

Salah satu asumsi model regresi berganda adalah tidak terdapat hubungan yang sempurna di antara variabel independen (multikolinearitas). Variance Inflation Factors (VIF) adalah metode formal untuk mendeteksi multikolinearitas, yang menyatakan sejauh mana kisaran estimasi koefisien regresi telah meningkat di atas nilai idealnya[5]. VIF untuk koefisien regresi-j adalah sebagai berikut :

$$
V I F_{j}=\frac{1}{1-R_{j}^{2}}
$$

Dengan $R_{j}^{2}$ adalah koefisien determinasi antara $X_{j}$ dengan variabel independen lainnya dalam persamaan/model prediktif, dimana $j=1,2, \ldots, p[6]$.

c. Uji Autokorelasi

Asumsi lain dari model regresi dengan metode OLS adalah tidak ada masalah autokorelasi atau korelasi serial antar residual $\left(e_{t}\right)$. Dengan kata lain, untuk semua $i \neq j$, sisanya adalah ekspansi bebas atau $\operatorname{Cov}\left(e_{i}, e_{j}\right)=E\left(e_{i}, e_{j}\right)=0$

\section{d. Uji Heterokedastisitas}

Asumsi dasar penggunaan metode OLS untuk membentuk model regresi adalah varian error setiap data observasi konstan, Var $(e)=\sigma^{2}$. Dengan kata lain, varian/ragam sisaan bersifat homogen untuk tiap pengamatan ke-i. Asumsi ini disebut homoskedastisitas. Jika model regresi tidak memenuhi asumsi homoskedastisitas maka model regresi mengalami akan menemui masalah heteroskedastisitas[7].

\section{METODOLOGI}

Penelitian ini menggunaan metode regresi linear berganda yang diolah dengan software $R$ untuk menganalisis datanya. Data dalam penelitian ini merupakan data sekunder yang diperoleh dari Badan Pusat Statistik Kabupaten Gowa tahun 2010-2018. Tabel 3.1 berikut mencantumkan variabel yang digunakan dalam penelitian ini.

Tabel 3.1. Definisi Operasional Variabel

\begin{tabular}{cl}
\hline $\begin{array}{c}\text { Nama } \\
\text { Variabel }\end{array}$ & \multicolumn{1}{c}{ Definisi } \\
\hline Pra & $\begin{array}{l}\text { Banyaknya penduduk } \\
\text { yang kurang mampu } \\
\text { (belum sejahtera). Satuan } \\
\text { data yang digunakan ialah } \\
\text { jiwa. }\end{array}$ \\
Sejahtera (Y) \\
Banyaknya keseluruhan \\
penduduk mulai dari bayi \\
Jumlah & $\begin{array}{l}\text { sampai dengan lansia. } \\
\text { Penduduk }\left(X_{1}\right)\end{array}$ \\
& $\begin{array}{l}\text { Satuan data yang } \\
\text { digunakan ialah jiwa. }\end{array}$ \\
Banyaknya penduduk \\
wanita yang telah \\
menikah dan masih aktif \\
menggunakan \\
berjenis apapun. Satuan \\
data yang digunakan ialah \\
Akseptor KB $\left(X_{2}\right)$ \\
jiwa.
\end{tabular}

Adapun langkah-langkah langkah-langkah yang dilakukan pada penelitian ini, dapat menggunakan prosedur penelitian sebagai berikut.

1. Mengumpulkan data dari BPS Kabupaten Gowa terkait data yang terdapat di 
Kecamatan Pattallassang khususnya di Desa Borong Pa'la'la.

2. Mendeskripsikan karakteristik data dengan menggunakan statistika deskriptif.

3. Menentukan model regresi dari analisis regresi linear berganda.

4. Melakukan uji kelayakan model yang meliputi :

a. Uji Serentak (Uji- $F)$

b. Uji Parsial (Uji- $t$ )

5. Memilih variabel yang terkategori sebagai prediktor terbaik kemudian dimasukkan ke dalam model.

6. Melakukan uji asumsi klasik yang terdiri dari :
a. Uji Normalitas
b. Uji Multikolinearitas
c. Uji Heteroskedastisitas
d. Uji Autokorelasi

7. Menghitung nilai koefisien determinasi $\left(R^{2}\right)$.

8. Melakukan interpretasi serta menarik kesimpulan dan memberikan saran untuk penelitian selanjutnya.

\section{PEMBAHASAN}

Data yang digunakan pada penelitian setiap tahunnya mengalami fluktuatif yang mengindikasikan bahwa setiap tahun selalu mengalami perubahan. Perubahan tersebut terkadang konstan, meningkat, bahkan mengalami penurunan.

\section{Statistik Deskriptif}

Untuk melihat karakteristik tersebut, maka ditampilkan pada tabel 4.1 berikut.

Tabel 4.1. Statistik Deskriptif

\begin{tabular}{ccccc}
\hline Variabel & Min. & Max. & Median & Mean \\
\hline$(\mathrm{Y})$ & 135 & 185 & 163 & 162,8 \\
$\left(X_{1}\right)$ & 1558 & 1714 & 1668 & 1651 \\
$\left(X_{2}\right)$ & 202 & 247 & 202 & 214,7 \\
\hline
\end{tabular}

\section{Pendugaan Model}

Berdasarkan hasil analisis, terbentuklah model awal, yaitu

$$
\widehat{y}=478,0891-0,1455 X_{1}-0,3498 X_{2}
$$

\section{Uji Serentak (Uji-F)}

Berdasarkan analisis dari uji Serentak (Uji-F), diperoleh hasilnya yang tercantum pada gambar 4.1 berikut.

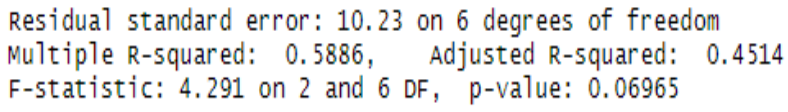

\section{Gambar 4.1. Hasil Uji- $F$}

Berdasarkan hasil analisis pada gambar 4.1, hasil dari uji- $F$ sebesar 0,06965 . Hal ini berarti bahwa $P$-Value $>0,05$, sehingga model regresi yang diestimasi layak untuk digunakan untuk menjelaskan pengaruh jumlah penduduk dan akseptor KB aktif terhadap variabel pra sejahtera.

\section{Uji Parsial (Uji-t)}

Berdasarkan analisis dari uji Parsial (uji-t), diperoleh hasilnya yang tercantum pada gambar 4.2 berikut.

\begin{tabular}{lrrrr} 
Coefficients: & \multicolumn{3}{c}{} & \\
& Estimate & Std. Error $\mathrm{t}$ value $\operatorname{Pr}(>|\mathrm{t}|$ ) \\
(Intercept) & 478.08913 & 109.08514 & 4.383 & 0.00465 \\
Jumlah. Penduduk & -0.14547 & 0.06027 & -2.414 & 0.05230 \\
Akseptor. KB. Aktif & -0.34978 & 0.21722 & -1.610 & 0.15847
\end{tabular}

\section{Gambar 4.2. Hasil Uji-t}

Berdasarkan hasil analisis pada gambar 4.2, dapat ditarik kesimpulan bahwa pada variabel jumlah penduduk $\left(X_{1}\right)$ dan akseptor KB aktif $\left(X_{2}\right)$ memiliki $P$-Value $>0,05$, sehingga kedua variabel tersebut berpengaruh signifikan secara parsial terhadap variabel Pra Sejahtera (Y).

\section{Pemilihan Model Terbaik}

Dalam melakukan model terbaik, menggunakan Metode Stepwise. Berdasarkan analisis dari Metode Stepwise, diperoleh hasilnya yang tercantum pada gambar 4.3. Berdasarkan hasil analisis pada gambar 4.3, dapat ditarik kesimpulan bahwa, semua variabel bebas memenuhi kriteria dan berpengaruh signifikan dan merupakan model terbaik terhadap variabel Pra Sejahtera. Sehingga, model regresi yang terbentuk ialah :

$$
\bar{y}=478,0891-0,1455\left(X_{1}\right)-0,3498\left(X_{2}\right)
$$




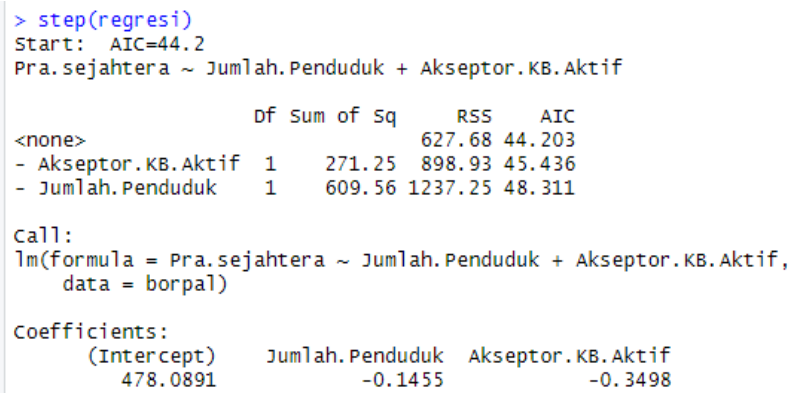

Gambar 4.3. Hasil Metode Stepwise

Dari persamaan regresi tersebut, menghasilkan nilai konstanta sebesar 478,0891. Hal ini berarti bahwa apabila variabel jumlah penduduk $\left(X_{1}\right)$ dan variabel akseptor KB aktif $\left(X_{2}\right)$ diasumsikan konstan, maka diperkirakan rasio pra sejahtera sebesar 478,0891 jiwa/orang selama periode tahun 2010-2018.

Koefisien regresi $\left(X_{1}\right)$ bernilai negatif artinya pada saat pertumbuhan jumlah penduduk $\left(X_{1}\right)$ menurun, maka angka pra sejahtera (Y) meningkat. Begitupun sebaliknya, jika pada saat pertumbuhan jumlah penduduk $\left(X_{1}\right)$ meningkat, maka angka pra sejahtera (Y) menurun. Bertambahnya angka pra sejahtera sebesar $1 \%$, akan menurunkan persentase jumlah penduduk sebesar $0,1455 \%$, sebaliknya berkurangnya angka pra sejahtera sebesar 1\%, akan menaikkan persentase jumlah penduduk sebesar $0,1455 \%$.

Sama halnya koefisien regresi $\left(X_{1}\right)$, pada koefisien regresi $\left(X_{2}\right)$ juga bernilai negatif yang berarti bahwa pada saat jumlah akseptor KB aktif $\left(X_{2}\right)$ menurun, maka angka pra sejahtera (Y) meningkat. Begitupun sebaliknya, jika pada saat jumlah akseptor KB aktif $\left(X_{2}\right)$ meningkat, maka angka pra sejahtera (Y) menurun. Bertambahnya angka pra sejahtera sebesar 1\%, akan menurunkan persentase jumlah akseptor KB aktif sebesar 0,3498\%, sebaliknya berkurangnya angka pra sejahtera sebesar $1 \%$, akan menaikkan persentase jumlah akseptor KB aktif sebesar 0,3498\%.

\section{Uji Normalitas}

Untuk uji normalitas pada penelitian ini, menggunakan uji Shapiro-Wilk yang tercantum pada gambar 4.4 berikut. Uji ini digunakan karena valid digunakan jika jumlah datanya < 50 data.

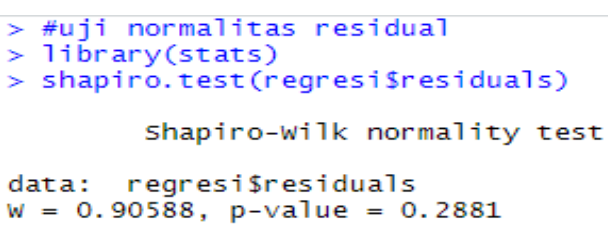

Gambar 4.4. Hasil Uji Shapiro-Wilk

Dari hasil analisis, menghasilkan nilai signifikansi ( $p$-value) sebesar 0,2881. Hal ini menunjukkan 0,2881 >0,05 yang berarti bahwa data berdistribusi normal.

\section{Uji Multikolinearitas}

Berdasarkan analisis dari uji multikolinearitas, diperoleh hasilnya yang tercantum pada gambar 4.5 berikut.

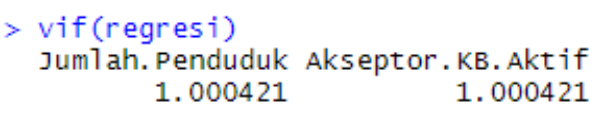

Gambar 4.5. Hasil Uji VIF

Berdasarkan gambar 4.5, menunjukkan bahwa kedua variabel memiliki nilai VIF $<10$. Hal ini mengindikasikan jika nilai VIF $<10$, berarti bahwa data tidak bersifat multikolinearitas.

\section{Uji Heteroskedastisitas}

Berdasarkan analisis dari uji heteroskedastisitas, diperoleh hasilnya yang tercantum pada gambar 4.6 berikut.

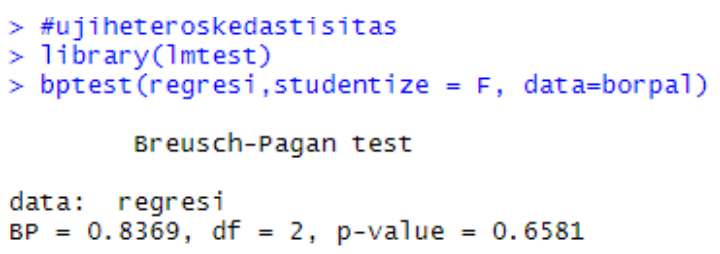

Gambar 4.6. Hasil Uji Heteroskedastisitas

Berdasarkan gambar 4.6, menunjukkan bahwa p-value sebesar 0,6581. Hal ini mengindikasikan, 0,6581 >0,05 maka data bersifat homoskedastisitas. Oleh karena data bersifat homoskedastisitas, dan tidak terjadi heteroskedastisitas, maka data telah memenuhi syarat dalam pemodelan regresi. 


\section{Uji Autokorelasi}

Berdasarkan analisis dari uji autokorelasi, diperoleh hasilnya yang tercantum pada gambar 4.7 berikut.

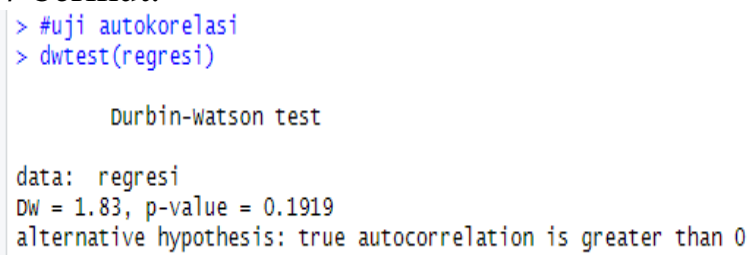

Gambar 4.7. Hasil Uji Autokorelasi

Berdasarkan gambar 4.7, menunjukkan bahwa nilai Durbin-Watson sebesar 1,83. Hal ini mengindikasikan, Nilai $-2 \leq D W \leq 2$ yang berarti bahwa data tidak bersifat autokorelasi.

\section{Koefisien Determinasi $\left(\boldsymbol{R}^{2}\right)$}

Berdasarkan analisis dari koefisien determinasi $\left(R^{2}\right)$, diperoleh hasilnya yang tercantum pada gambar 4.8 berikut.

Residual standard error: 10.23 on 6 degrees of freedom Multiple R-squared: 0.5886 , Adjusted R-squared: 0.4514 F-statistic: 4.291 on 2 and 6 DF, p-value: 0.06965

Gambar 4.8. Hasil Uji $-R^{2}$

Berdasarkan hasil dari gambar 4.8, diperoleh nilai koefisien determinasi $\left(R^{2}\right)$ sebesar 0,5866 . Hal ini berarti bahwa pengaruh variabel jumlah penduduk $\left(X_{1}\right)$ dan variabel akseptor KB aktif $\left(X_{2}\right)$ terhadap variabel pra sejahtera $(Y)$ sebesar 0,5866 dan selebihnya dipengaruhi oleh variabel lain. Karena $\left(R^{2}\right)$ mendekati satu model maka model dikatakan baik (Goodness Of Fit).

\section{KESIMPULAN}

Berdasarkan hasil penelitian, maka kesimpulannya ialah variabel jumlah penduduk dan akseptor KB aktif berpengaruh negatif dan signifikan terhadap variabel pra sejahtera di Desa Borong Pa'la'la.

\section{DAFTAR PUSTAKA}

[1] Hasma, Muh. Mustakim. Data Dan Informasi Kemiskinan Provinsi Sulawesi Selatan 2019. Sulawesi Selatan: Badan Pusat Statistik, 2019.
[2] Zahra, Afifatus, dkk. Struktur Kemiskinan Indonesia: Berapa Besar Pengaruh Kesehatan, Pendidikan Dan Kelayakan Hunian?. Jurnal Inovasi Ekonomi. Vol. 04, No. 02, 2019.

[3] Riduwan. Dasar-Dasar Statistika. Bandung : ALFABETA, 2003.

[4] Tim Dosen Ekonometrika. Buku Pedoman Praktikum Ekonometrika. Universitas Brawijaya Malang (2015).

[5] Utami, Ni Ketut Tri, dkk. Penerapan Metode Generalized Ridge Regression Dalam Mengatasi Masalah Multikolinearitas. E-Jurnal Matematika. Vol. 2 No. 1. 2013.

[6] Sriningsih ,Mega, dkk. Penanganan Multikolinearitas Dengan Menggunakan Analisis Regresi Komponen Utama Pada Kasus Impor Beras Di Provinsi Sulut. Ilmiah Sains. Vol. 18 No. 2018).

[7] Widarto, Rachbini, dkk. Statistika Terapan. Jakarta : Mitra Wacana Media. 2018. 